\title{
IMPLEMENTASI METODE SAW DALAM SISTEM PENDUKUNG KEPUTUSAN PEMILIHAN MODEL SOCIAL CUSTOMER RELATIONSHIP MANAGEMENT
}

\author{
Rus liyawati $^{1}$, Damayanti ${ }^{2}$, Sefrizal Nata Prawira ${ }^{3}$ \\ ${ }^{1,2,3}$ Program Studi Sistem Informasi, Fakultas Teknik dan Ilmu Komputer \\ Universitas Teknokrat Indonesia \\ rusliyawati@teknokrat.ac.id, damayanti@teknokrat.ac.id, febrizalnataprawira@gmail.com
}

\begin{abstract}
Abstrak
Pertumbuhan dan perkembangan internet serta sosial media yang berkembang pesat memunculkan perkembangan baru dari Customer Relationship Management (CRM) yaitu Social Customer Relationship Management (SCRM) yang menuntut organisasi menetapkan arah strategi bisnis dengan pengaplikasian teknologi sesuai kebutuhan dalam berbagai aktivitas sehingga mampu meningkatkan perubahan bisnis skala besar melalui kecepatan, ketepatan dan efisiensi dari pertukaran informasi. Kualitas strategi bisnis yang baik dapat dilakukan dengan cara penyediaan fasilitas berbasis media sosial dengan pertimbangan yang sangat matang yaitu dengan cara menilai berbagai indikator penilaian yang sudah ditentukan terhadap sosial media yang dapat memberikan kontribusi yang baik bagi perusahaan sebagai salah satu strategi bisnis yang dipilih oleh perusahaan. Tujuan penelitian ini untuk menganalisis perhitungan karakteristik dari setiap model social customer relationship management (SCRM) sebagai strategi bisnis dengan menggunakan metode pendekatan Simple Additive Weighting (SAW). Hasil penelitian menunjukan bahwa media sosial Youtube dengan perolehan nilai 0,888 adalah media sosial yang direkomendasikan untuk digunakan sebagai strategi bisnis perguruan tinggi.
\end{abstract}

Kata Kunci: Social Customer Relationship Management, Simple Additive Weighting, Strategi Bisnis

\begin{abstract}
The growth and development of the internet and rapidly growing social media have led to new developments in Customer Relationship Management (CRM), namely Social Customer Relationship Management (SCRM), which requires organizations to determine the direction of business strategies by applying technology as needed in various activities so as to increase large-scale business change. through the speed, accuracy and efficiency of information exchange. The quality of a good business strategy can be done by providing social mediabased facilities with very mature considerations, namely by assessing various predetermined assessment indicators of social media that can make a good contribution to the company as one of the business strategies chosen by the company. The purpose of this study is to analyze the calculation of the characteristics of each social customer relationship management (SCRM) model as a business strategy using the Simple Additive Weighting (SAW) approach. The results showed that YouTube social media with a score of 0.888 was the recommended social media to be used as a college business strategy.
\end{abstract}

Keywords: Customer Relationship Management, Simple Additive Weighting, Business Strategy 


\section{PENDAHULUAN}

Revolusi industri 4.0 merupakan bentuk kemajuan teknologi yang mengintegrasikan dunia fisik, digital, dan biologis, yang berakibat terjadinya perubahan besar dalam melakukan aktivitas atau kegiatan (Kagermann, Lukas, \& Wahlster, 2011) dalam memutar roda organisasi (Lekara, 2019) sehingga memicu perusahaan untuk mengalokasikan anggaran investasi modal dalam bidang teknologi informasi yang tepat guna sesuai kebutuhan (Hertingkir \& Wardani, 2017). Aktivitas organisasi saat ini tidak terlepas dari penerapan aplikasi dan sistem informasi yang saling terintegrasi sehingga menuntut organisasi mampu menetapkan arah strategi bisnis sesuai kebutuhan untuk meningkatkan perubahan bisnis dalam skala besar melalui kecepatan, ketepatan dan efisiensi dari pertukaran informasi (Cascio \& Montealegre, 2016).

Setiap tahun jumlah unit perguruan tinggi di Indonesia semakin bertambah. Saat ini jumlah perguruan tinggi yang terdaftar di Indonesia mencapai 5.660 unit. Semakin ketatnya persaingan antara perguruan tinggi satu dan lainnya mengakibatkan setiap perguruan tinggi harus melakukan berbagai upaya untuk mengelola institusinya secara profesional khususnya pemberian pelayanan yang berkualitas pada pelanggan (Tremblay, Lalancette, \& Roseveare, 2012). Identifikasi dan memahami pelanggan merupakan salah satu strategi untuk memenangkan persaingan bisnis (Andajani \& Badriyah, 2017).

Kualitas strategi bisnis yang baik dapat dilakukan dengan cara penyediaan fasilitas berbasis media sosial dengan pertimbangan yang sangat matang yaitu dengan cara menilai berbagai indikator penilaian yang sudah ditentukan terhadap sosial media yang dapat memberikan kontribusi yang baik bagi perusahaan sebagai salah satu strategi bisnis yang dipilih oleh perusahaan (Nguyen, Le, Tran, \& Tran, 2020). Kemajuan teknologi dan informasi membuat media sosial dan internet tak terpisahkan satu sama lainnya, hal ini dibuktikan pengguna internet dan sosial media yang semakin tahun semakin bertambah. Pada tahun 2018 jumlah pengguna internet dan sosial 
media mencapai 4 miliar atau setara dengan 52,96\% dari total populasi dunia yang berjumlah 7,59 miliar orang (Sumber, Indonesian Digital Report 2019). Para pengguna internet dan sosial media mengunjungi situs jejaring sosial sebulan setidaknya sekali dan jumlah pengguna internet dan sosial media tumbuh dari $41 \%$ d itahun 2008 menjadi 65\% di tahun 2014 (Heidemann, Klier, \& Probst, 2012). Fungsi media sosial dalam suatu organisasi dapat menjadi tempat untuk mempromosikan produk atau jasa yang dimiliki lalu dapat menciptakan sebuah komunitas online (Kaplan \& Haenlein, 2009). Melihat pertumbuhan dan perkembangan internet serta sosial media yang berkembang pesat muncul perkembangan baru dari Customer Relationship Management (CRM) yaitu Social Customer Relationship Management (SCRM). CRM menandakan seluruh proses menjalin dan menjaga hubungan dengan pelanggan, dimana hubungan tersebut dapat menjadi jalan untuk memaksimalkan loyalitas pelanggan (Lovelock, Wirtz, \& Mussry, 2013), sedangkan SCRM merupakan perpaduan dari CRM dan media sosial yang menggabungkan elemenelemen konseptual media sosial dan CRM meliputi jaringan sosial, teknologi komunikasi, komunitas, strategi, nilai pelanggan, dan hubungan (Greenberg, 2009). Penggabungan fitur jejaring sosial untuk menganalisa perilaku SCRM penerima dan pengguna, serta pelanggan bisnis (Askool \& Nakata, 2011) melibatkan pelanggan untuk mengenali prilaku keterlibatan dan kemampuan perusahaan untuk menangkap dan meneruskan nilai kembali kepada pelanggan (Kunz, et al., 2017).

\section{Metode Simple Additive} Weighting atau lebih dikenal dengan SAW merupakan metode perhitungan yang dilakukan dengan cara penentuan alternatif-alternatif yang mana tiap alternatif akan dinilai berdasarkan kriteria yang juga telah ditentukan serta telah diberi bobot pada masing-masing penilaian kriteria (Wantoro, Muludi, \& Sukisno, 2019). Pengambilan keputusan pemilihan model SCRM yang tepat melalui penilaian indikator yang ditentukan terhadap media sosial menggunakan metode SAW. 
Penelitian ini adalah pengembangan penelitian (Baktiono \& Artaya, 2016) sebelumnya tentang memilih media sosial sebagai sarana bisnis online melalui pendekatan uji categorical dengan variabel yang digunakan yaitu media sosial facebook, twitter, google+, dan instagram. Penelitian lain (Priliyani, Rusliyawati, \& Damayanti, 2019) yang menggunakan variabel media sosial richness dan frequently content. Hasil penelitian yaitu bahwa loyalitas civitas akademika perguruan tinggi secara parsial dipengaruhi oleh variabel richness.

Perbedaan penelitian ini dengan penelitian sebelumnya adalah variabel independen menggunakan media sosial youtube, whatsapp, facebook, dan instagram, sedangkan variabel dependen model SCRM menggunakan metode SAW. Penelitian ini mengusulkan untuk mengembangkan sebuah aplikasi yang berfungsi untuk menganalisis dan penghitungan karakteristik dari setiap model SCRM sebagai strategi bisnis. Manfaat dari aplikasi yang akan dikembangkan yaitu untuk mempermudah perusahaan dalam hal pengambilan keputusan dalam memilih model SCRM sebagai penunjang strategi bisnis perguruan tinggi.

\section{METODE PENELITIAN}

Tahapan Penelitian

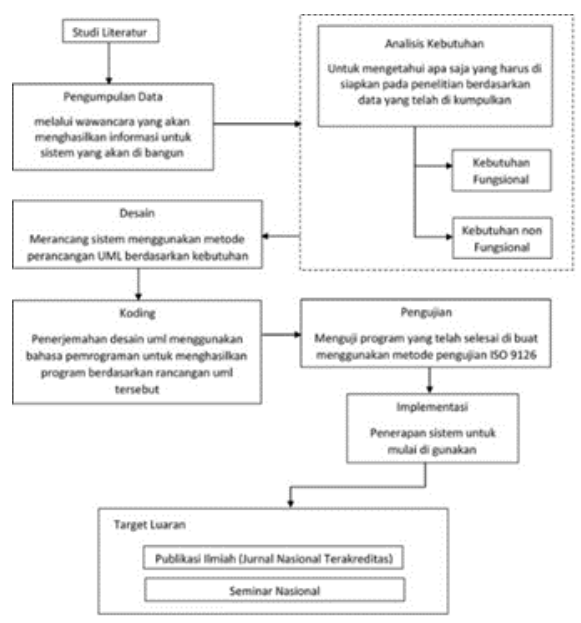

Gambar 1. Tahapan Penelitian

Pendekatan kuantitatif sebagai proses penggalian informasi (Sugiyono, Metodologi Penelitian Kuantitatif Kualitatif, 2015) digunakan dalam penelitian ini dengan tahapan penelitian sesuai pada Gambar 1. Untuk melaksanakan penelitian ini telah dilakukan tahap awal yaitu studi literatur, dengan membaca beberapa penelitian terkait dengan sistem pendukung keputusan dan SCRM. Dari hasil studi literatur didapatkan beberapa calon kriteria, yaitu: 
a. Penelitian memilih media sosial sebagai sarana bisnis online melalui pendekatan uji categorical: Mudah dijalankan, Mudah diakses, Tampilan menarik, Fleksibel dan atraktif, Digunakan oleh banyak orang, Jangkauan tidak terbatas, Memiliki fasilitas link dengan media sosial lain, Memiliki tingkat keamanan, Biaya paling murah, Teknik penyajian dan posting mudah, Fitur dan fasilitas memadai, Membuka peluang akses, Dapat digunakan untuk pengenalan bisnis, Terhubung dengan komunitas bisnis, Dapat digunakan untuk Chat, Penyampaian pesan lebih efektif (Voorveld H. A., Noort, Muntinga, \& Bronner, 2018).

b. Penelitian SCRM sebagai strategi bisnis: Jaringan yang mudah, Partisipan yang mudah, Kolaborasi yang mudah, Familiar, Peduli, Memberi kegunaan, Mudah digunakan, Dapat dipercaya, Perilaku pengguna (Hart \& Kassem, Social Customer Relationship Management - From Customer to Friend, 2012).

\section{HASIL PENELITIAN DAN \\ PEMBAHASAN}

Analisis SAW ini bertujuan untuk menentukan alternatif yang akan dinilai beserta kriteria penilaian yang akan dinilai nantinya dari masing-masing alternatif. Berdasarkan penelitian sebelumnya dan hasil wawancara dengan pihak terkait untuk menentukan kriteria, bobot kriteria, dan nama alternatif pada sistem pendukung keputusan pemilihan model sosial CRM sebagai strategi bisnis perguruan tinggi dengan metode SAW. Bobot preferensi atau tingkatan kepentingan dari setiap indikator, diberikan nilai pada setiap indikator, dimana penentuan bobot preferensi atau tingkat kepentingan ini di ambil dari hasil pembahasan wawancara yang telah dilakukan terhadap bagian informasi Universitas. Berdasarkan perhitungan yang telah dilakukan penilaian terhadap tiap alternatif didapatkan skor pada Tabel 1.

Berdasarkan tabel diketahui bahwa terdapat empat variabel penelitian (Youtube, Whatsapp, Facebook, dan Instagram) dengan jumlah sampel secara keseluruhan sebanyak 552 responden. 
Tabel 1. Hasil Pengolahan SAW

\begin{tabular}{ccc}
\hline No & Alternatif & Hasil \\
\hline 1 & Youtube & 0.888 \\
2 & Whatsapp & 0.825 \\
3 & Facebook & 0.808 \\
4 & Instagram & 0.828 \\
\hline
\end{tabular}

Hasil

pengolahan

merekomendasikan

alternatif

Youtube untuk digunakan sebagai model Social Customer Relationship Management dengan nilai 0,888. Dari hasil perhitungan di atas menggunakan metode SAW dapat dilihat hasil terbesar berada media youtube, sehingga rekomendasi alternatif ialah Youtube.

\section{KESIMPULAN DAN SARAN}

Berdasarkan pembahasan, maka simpulan penelitian adalah Hasil implementasi penilaian terhadap alternatif media sosial dengan ketentuan kriteria yang telah ditentukan dan populasi penilai mahasiswa program studi sistem informasi angkatan 2017, 2018, dan 2019 didapatkan hasil bahwa media sosial Youtube dengan perolehan nilai 0,888 adalah media sosial yang direkomendasikan untuk digunakan sebagai strategi bisnis perguruan tinggi. Berdasarkan penelitian diatas maka sarankan pada pengembagan pnelitian selanjutnya hendaknya menambah jumlah sampel dan menggunakan variabel dependen media sosial yang lain.

\section{UCAPAN TERIMA KASIH}

Penulis mengucapkan terima kasih kepada Kementrian Riset dan Teknologi / Badan Riset dan Inovasi Nasional (KEMENRISTEK/BRIN) yang telah memberi dukungan pendanaan/financial terhadap penelitian ini melalui skema Penelitian Dosen Pemula (PDP) tahun 2020.

\section{DAFTAR PUSTAKA}

Andajani, E., \& Badriyah, N. (2017). The Role of Customer Relationship Management in Indonesia Business. Jurnal Ilmiah Bidang Akuntansi dan Manajemen (JEMA), 1-7.

Askool, S., \& Nakata, K. (2011). A Conceptual model for acceptance of social CRM systems based on a scoping study. Journal of Knowledge, Culture and Communication (AI \& Society), 205-220.

Baktiono, A. R., \& Artaya, I. P. (2016). Memilih Media Sosial Sebagai Sarana Bisnis Online 
Melalui Pendekatan Uji Categorical. e-Jurnal Manajemen Kinerja, 1-8.

Cascio, W. F., \& Montealegre, R. (2016). How Technology is Changing Work and Organizations. California: Knowable Magazine Annual Review.

Greenberg, P. (2009). CRM at the Speed of Light, Fourth Edition: Social CRM 2.0 Strategies, Tools, and Techniques for Engaging Your Customers. New York: McGraw-Hill Education; 4th Edition.

Hart, S., \& Kassem, G. (2012). Social Customer Relationship Management - From Customer to Friend. European, Mediterranean \& Middle Eastern Conference on Information Systems, (pp. 7588). Munich, Germany.

Hart, S., \& Kassem, G. (2012). Social Customer Relationship Management from Customer to Friend. European, Mediterranean \& Middle Eastern Conference on Information System 2012. Munich.

Heidemann, J., Klier, M., \& Probst, F. (2012). Online Social Networks: A Survey of a Global Phenomenon. Computer Networks, Elsevier, 3866-3878.
Hertingkir, F., \& Wardani, D. (2017). Analisis Kelayakan Anggaran Investasi Teknologi Informasi dengan Analisis Cost Benefit. Jurnal Keuangan dan Perbankan, 9-17.

Kagermann, H., Lukas, W. D., \& Wahlster, W. (2011). Industrie 4.0: Mit dem Internet der Dinge auf dem Weg zur 4. indusriellen Revolution. Berlin: VDI nachrichten.

Kaplan, A. M., \& Haenlein, M. (2009). Users of the world, unite! The challenges and opportunities of Social Media. Business Horizons, Elsevier, 59-68.

Kunz, W. H., Aksoy, L., Bart, Y., Heinonen, K., Kabadayi, S., Ordenes, F. V., . . . Theodoulidis, B. (2017). Customer Engagement in a Big Data World. Journal of Services Marketing, 161-171.

Lekara, B. P. (2019). Technological Challenges in Management of Organizations. International Journal of Business \& Law Research, 99-111.

Lovelock, C., Wirtz, J., \& Mussry, J. (2013). Pemasaran Jasa, Perspektif Indonesia Jilid 1 \& 2. Jakarta: Erlangga.

Nguyen, H. N., Le, Q. H., Tran, Q. B., \& Tran, T. M. (2020). The Impact of Organizational 
Commitment on Employee Motivation: A Study in Vietnamese Enterprise. Journal of Asian Finance, Economics and Business , 439-447.

Priliyani, H., Rusliyawati, \& Damayanti. (2019). Pengaruh Media Richness dan Frequently Update Terhadap Loyalitas Civitas Akademika Perguruan Tinggi. Jurnal TEKNOKOMPAK, 7-10.

Sugiyono. (2015). Metodologi Penelitian Kuantitatif Kualitatif. Bandung: Alfabetha.

Sugiyono. (2015). Metodologi Penelitian Kuantitatif Kualitatif . Bandung: Alfabetha.

Tremblay, K., Lalancette, D., \& Roseveare, D. (2012). Assessment of Higher Education Learning Outcomes. Paris: AHELO Feasibility Study Report.

Voorveld, H. A., Noort, G. v., Muntinga, D. G., \& Bronner, F. (2018). Engagement with Social Media and Social Media Advertising: The Differentiating Role of Platform Type. Journal of Advertising, 47(1), 1-17.

Voorveld, H. A., Noort, G. V., Muntinga, D. G., \& Bronner, F. (2018). Enggagement with Social Media and Social Media
Advertising: The Differentiating Role of Platform. Journal of Advertising, 38-54.

Wantoro, A., Muludi, K., \& Sukisno. (2019). Penerapan Logika Fuzzy pada Sistem Pendukung Keputusan Penentuan Kelayakan Kualitas Telur Bebek. Journal Teknik Informatika UNIS, 1-6. 